\title{
COMUNICACÕES
}

\section{Berkeleyomyces basicola causing root rot on carrots (Daucus carota) in the state of Bahia, Brazil}

Deisy Janiny Gonçalves Silva ${ }^{1} \mathbb{D}$; Elizabeth Amélia Alves Duarte ${ }^{2} \mathbb{D}$; José Luiz Bezerra ${ }^{1,3} \mathbb{D}$; Jadergudson Pereira ${ }^{1,4}$ [D; Thaís Marcelo Souza ${ }^{1}(\mathbb{D}$

${ }^{1}$ Programa de Pós-Graduação em Produção Vegetal - PPGPV, Universidade, Estadual de Santa Cruz (UESC), Rod. Jorge Amado, Km 16, CEP: 45.662-900, Ilhéus, Bahia, Brasil; ${ }^{2}$ Faculdade Maria Milza, Programa de Pós-Graduação em Biotecnologia, Rod. BR-101- Km 215 - Governador Mangabeira, Bahia, Brasil.; ${ }^{3}$ Universidade Federal do Recôncavo da Bahia, Centro de Ciências Agrárias, Ambientais e Biotecnológicas, Rua Rui Barbosa 710, 44380-000, Cruz das Almas, Bahia, Brasil.; ${ }^{4}$ Departamento de Ciências Agrárias e Ambientais, Universidade Estadual de Santa Cruz, Rodovia Jorge Amado km16, CEP: 45.662-900, Ilhéus, Bahia, Brasil.

Corresponding author: Deisy Janiny Gonçalves Silva (deisyjany@yahoo.com.br)

Data de chegada: 01/10/2018. Aceito para publicação em: 26/03/2021.

The carrot (Daucus carota L., Apiaceae) is very important worldwide. In Brazil, this vegetable is cultivated on a large scale in the southeast, northeast and southern regions. Considering Bahia State, the most important producing municipalities at present are Lapão, Irecê and João Dourado. Among postharvest diseases affecting carrots, black rot can cause significant losses.

In a commercial establishment in the municipality of Ilhéus, Bahia State, 'Brasília' carrot roots were found showing typical symptoms of black rot (Figure 1). The symptomatic material was taken to the Laboratory of Plant Pathology and Nematology of "Universidade Estadual de Santa Cruz (UESC)". A fungus was isolated in PotatoDextrose-Agar medium (PDA) in 9cm-diameter Petri dishes from fragments removed from the lesions, previously disinfested in $2 \%$

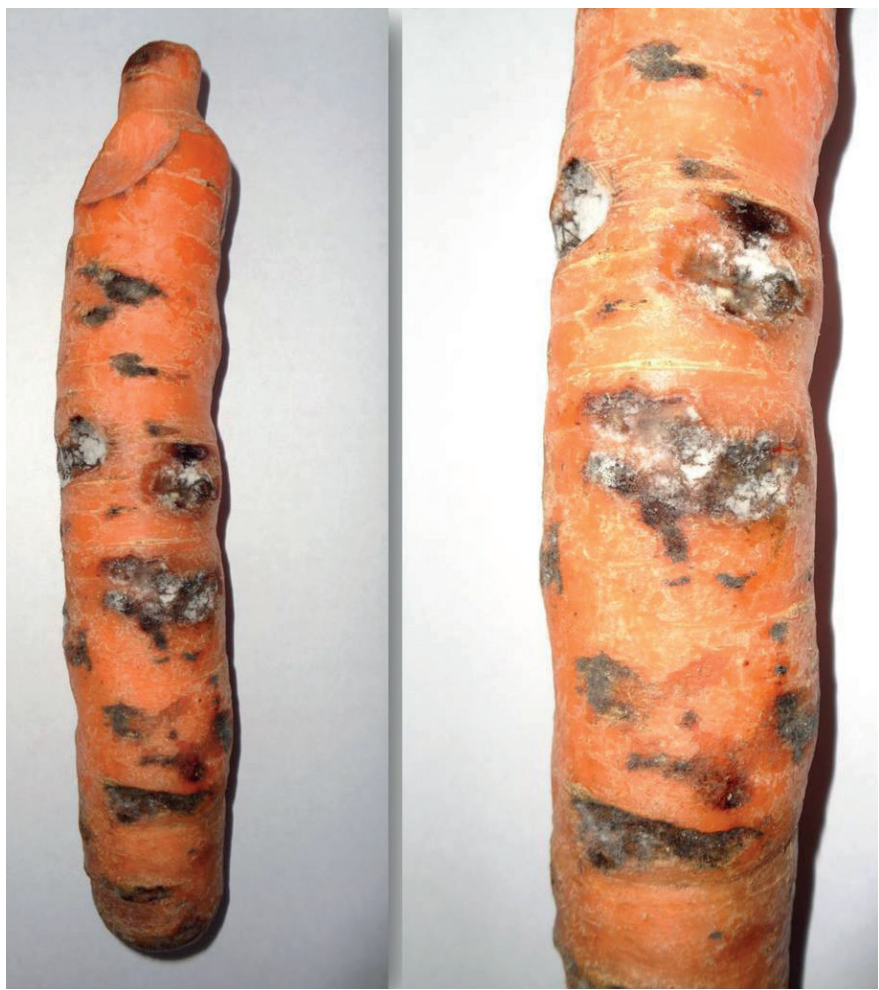

Figure 1. Natural infection of carrot roots by Berkeleyomyces basicola.

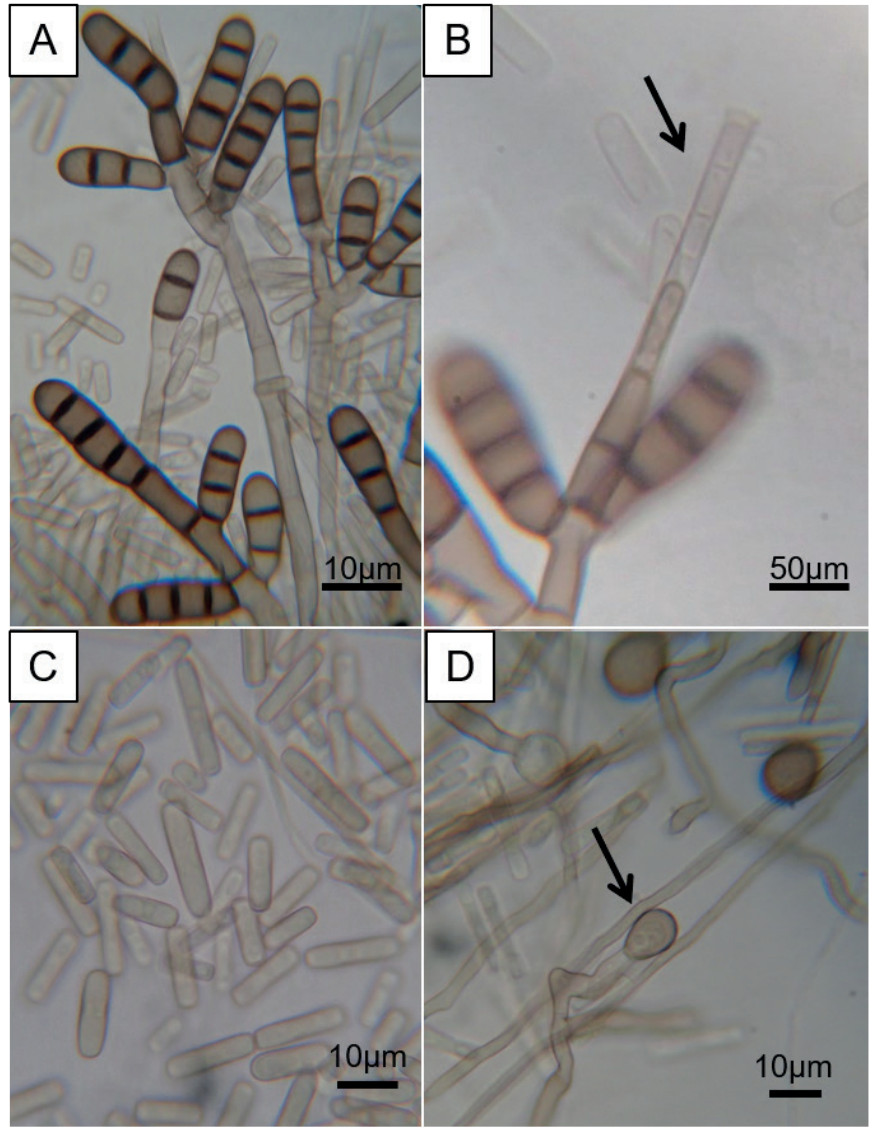

Figure 2 Asexual structures of Berkeleyomyces basicola. A artroconidia (chlamydospores); B - terminal phialide (arrow). C - unicellular cylindric phialoconidia. D - globose to pyriform aleuroconidia (Arrow).

sodium hypochlorite for 30 seconds and rinsed in sterile distilled water. Following incubation at $25 \pm 1{ }^{\circ} \mathrm{C}$ for 72 hours, the initial mycelium was transferred to new Petri dishes with PDA to obtain the pure culture. To verify the pathogenicity of the isolate, $50 \mu \mathrm{L}$ of a suspension of $2.5 \times 10^{6}$ phialoconidia / $\mathrm{mL}$ were inoculated into previously disinfested healthy carrot roots injured with a sterilized needle (five replicates). Sterile 
water was utilized as control. The inoculated roots were incubated in a humid chamber at $25 \pm 1{ }^{\circ} \mathrm{C}$ and four days after inoculation typical necrotic lesions were observed. Abundant reproductive structures of the fungus were observed under a light microscope (Figure 2): conidiophores 18-66 × 3-4 $\mu \mathrm{m}$, multicellular, dark brown, thick wall, 10-15 $\times 7-10 \mu \mathrm{m}$; phialides 57.5-212.5 $\times 5-7.5 \mu \mathrm{m}$ at the base and 2.5-5 $\mu \mathrm{m}$ at apex; phialoconidia $10-18 \times 4 \mu \mathrm{m}$, unicellular, cylindrical, hyaline. Based on such characteristics, Berkeleyomyces basicola (Berk. \& Broome) W.J. Nel, Z.W. de Beer, T.A. Duong \& M.J. Wingf. (synonyms: Thielaviopsis basicola [Berk. \& Broome] Ferraris; Chalara elegans Nag Raj \& W.B. Kendr.) was confirmed as the causal agent of the disease. Blades with reproductive structures and herborized fragments of infected roots were deposited in Tropical Fungarium (TFB 792), at UESC.

To our knowledge, this is the first report of B. basicola on D. carota in the state of Bahia. In Brazil, the fungus was previously reported in post-harvest carrots in Rio de Janeiro as Ceratocystis fimbriata Ellis \& Halst. (1), Rio Grande do Sul as C. elegans (2), and Federal District (3) and Maranhão (4) as T. basicola.

\section{REFERENCES}

1. Carvalho, A.O.; Carmo, M.G.F. Podridão pós-colheita de cenoura causada por Ceratocystis fimbriata. Fitopatologia Brasileira, Brasília, v.28, n.1, p.108, 2003.

2. Dalbosco, M.; El Tassa, S.O.M.; Duarte, V. Ocorrência de Podridão Negra, causada por Chalara elegans, em raízes de cenoura no Rio Grande do Sul. Fitopatologia Brasileira, Porto Alegre, v.29, n.3, p.336, 2004.

3. Inácio, C.A.; Lemes, G.P.; Café-Filho, A.C.; Lopes, C.A. First report of Thielaviopsis basicola causing black rot on carrot in Central Brazil. In: $45^{\circ}$ Congresso Brasileiro de Fitopatologia, Tropical Plant Pathology, Brasília, v. 37, Resumo 752, Suplemento, 1 CD-ROM, 2012.

4. Silva, G.S.; Costa, D.L.M.M. Ocorrência da podridão negra da cenoura no Estado do Maranhão. Summa Phytopathologica, Botucatu, v.39, n.4, p.294, 2013.

\section{ERRATA}

Na página 129, em um dos autores do artigo, onde se lia:

"Elisabeth Amélia Alves Duarte"

Leia-se:

"Elizabeth Amélia Alves Duarte"

Revista Summa Phytopathologica, v. 47, n. 3, 10.1590/0100-5405/214388a, 2021. 